Volume 9, Issue 1 (Winter 2017)

\title{
A Note on Rembrandt's Aristotle, Alexander, and Homer
}

Jeroen Giltaij

jgiltay@xs4all.nl

Recommended Citation:

Jeroen Giltaij, "A Note on Rembrandt's Aristotle, Alexander, and Homer," JHNA 9:1 (Winter 2017), DOI: 10.5092/jhna.2017.9.1.14

Available at https://jhna.org/articles/note-rembrandt-aristotle-alexander-homer/

Published by Historians of Netherlandish Art: https://hnanews.org/

Republication Guidelines: https://jhna.org/republication-guidelines/

Notes: This PDF is provided for reference purposes only and may not contain all the functionality or features of the original, online publication. This PDF provides paragraph numbers as well as page numbers for citation purposes.

ISSN: 1949-9833 


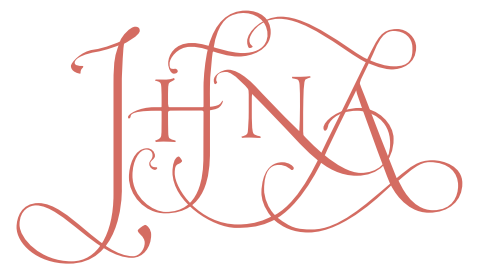

JOURNAL OF HISTORIANS OF NETHERLANDISH ART

A NOTE ON REMBRANDT'S ARISTOTLE, ALEXANDER, AND HOMER

\section{Jeroen Giltaij}

Although Walter Liedtke's catalogue of Dutch paintings in the Metropolitan Museum of Art includes an extensive entry about Rembrandt's Aristotle with a Bust of Homer, dated 1653 and ordered by the Sicilian nobleman Antonio Ruffo, he could not mention everything. This short note calls attention to an inventory of the collection of Antonio Ruffo from 1783, published by Rosanna De Gennaro, made after the earthquake of that year, with an extensive description of three paintings by Rembrandt. This article considers the implications of the 1783 inventory description for the history of the Aristotle and related works commissioned by Ruffo. D01:10.5092/jhna.2017.9.1.14

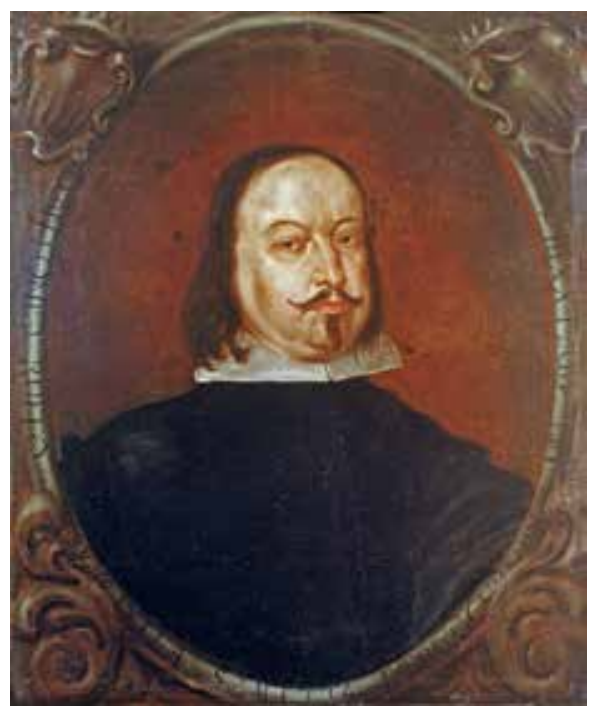

Fig. 1 Anonymous, Portrait of Antonio Ruffo, 1673, oil on canvas, approx. $90 \times 65 \mathrm{~cm}$, Messina, Arciconfraternità degli Azzurri (artwork in the public domain)

1 In 2007 Walter Liedtke published his monumental and important catalogue of the Dutch paintings in the Metropolitan Museum of Art, a catalogue he offered as a gesture "in honor of The Netherlands." He wrote an extensive entry on one of the most famous paintings in the museum, Rembrandt's Aristotle with a Bust of Homer, from 1653 (fig. 1). ${ }^{2}$ Totaling no less then twenty-five pages, including an introduction, notes on the work's early history, the subject and its significance, form, and content, and then eight pages with references, exhibitions, and provenance, the entry constitutes a monograph on this masterpiece. Walter mentions in his acknowledgments that he and I were faithful correspondents, usually about Rembrandt's Aristotle with a Bust of Homer, 
and I am thinking back with great pleasure to having had this great privilege of corresponding and speaking with him about different subjects.

Our contact started in 1990, when I visited him in his New York office to ask him, as a specialist on Dutch architectural painting of the seventeenth century, if he would be willing to write an essay for the catalogue of an exhibition on that subject at the Museum Boijmans van Beuningen. He immediately agreed and sent his interesting chapter: "The Court Style: Architectural Painting in The Hague and London," for the catalogue, which also includes introductions by J. M. Montias and Rob Ruurs. ${ }^{3}$ Soon after the exhibition we received the message that we had won the 1991 Minda De Gunzburg Prize, for the best scientific exhibition catalogue produced that year, in which the article by Walter had, of course, been an important contribution. ${ }^{4}$

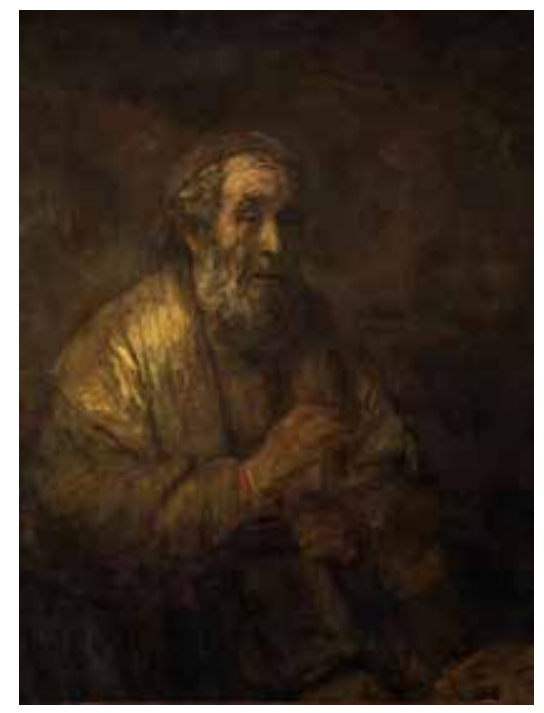

Fig. 2 Rembrandt, Homer Dictating His Verses, 1663, oil on canvas, $107 \times 82 \mathrm{~cm}$, signed and dated ... andt f. 1663. The Hague, Mauritshuis, inv. 584 (artwork in the public domain)

We were also in contact because of my dissertation on the Sicilian collector Antonio Ruffo, his collection, and his ordering of three paintings by Rembrandt, of which the Aristotle was one. ${ }^{5} \mathrm{I}$ was able to trace the family who owns letters from the collector to the artists ${ }^{6}$ and also the family member who owns the archives, in which several inventories of the collection turned up. The three paintings are the Aristotle from 1653, an Alexander the Great from 1661, now lost, and the Homer from 1663, now in the Mauritshuis in The Hague (fig. 2).

4 Liedtke compiled a very accurate and profound entry on the Aristotle, but he did not include every detail, which is, of course, impossible with such extensive literature. Here I should like to present some further considerations. With regard to the provenance, it was interesting to find in the family archives the inventories compiled when each successive owner died. The inventories of $1689,1703,1710$, and 1739 describe these three paintings; in the inventory of 1710 as follows:: "I.p. tre quadri con tre mezze figure grandi al naturale di pal. 8 e 6, uno Aristotile o sia Alberto Magno, che tien lo mano dritta s.pra una statua, e l'altro Allesandro Magno, che sta a sedere, e l'altro Omero anche a sedere, che sta insegnando dui discepoli tutti con loro cornici ed intagliati mano del Raimbrant Pittore Olandese." I concluded that after the last inventory (1739) was made the collection was probably disbursed. Proof of this seemed to be found in the fact that several important paintings were soon noted as being elsewhere. For example, the painting 
by Guercino, Erminia and the Shepherd, dated 1649, was recorded in 1772 in Castle Howard in York; it is now in the Minneapolis Institute of Arts. ${ }^{8}$ The paintings by Salvator Rosa, The History of Pythagoras: Buying Fishes (Berlin, Staatliche Museen Preusisscher Kulturbesitz, Gemäldegalerie) and The History of Pythagoras: Coming out of the Cave (Fort Worth, Texas, Kimbell Art Museum) were brought to England before 1770 by the painter Gavin Hamilton (1723-1798). ${ }^{9}$

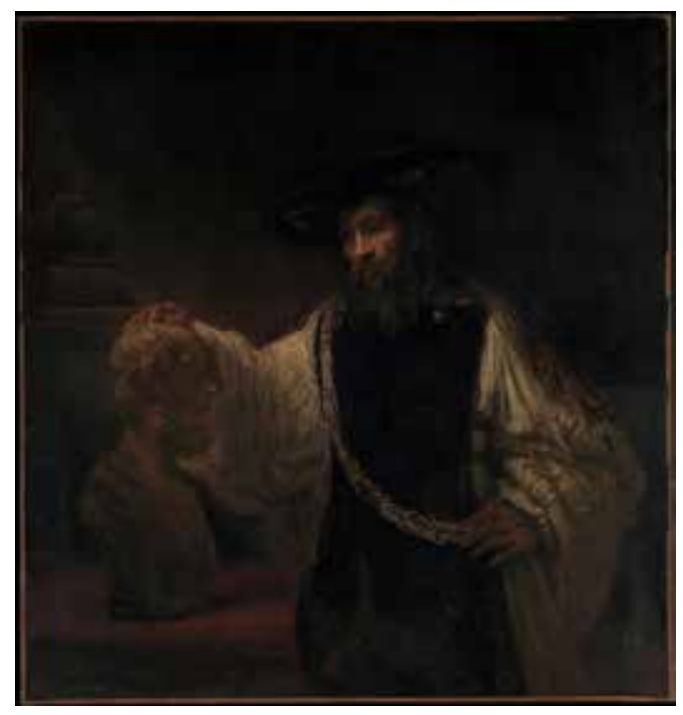

Fig. 3 Rembrandt, Aristotle with a Bust of Homer, 1653, oil on canvas, $143.5 \times 136.5 \mathrm{~cm}$, signed and dated Rembrandt.f./1653. New York, The Metropolitan Museum of Art, inv. 61.198 (artwork in the public domain)

Then, in 2001, an inventory dated 1783 was published. Soon thereafter Mario Alberto Pavone, professor at the Università di Salerno in Fisciano in the south of Italy, who had read my dissertation (with the help of friends, since it was published only in Dutch), visited me in Rotterdam to ask if I would write an article for the catalogue of an exhibition being organized for presentation in 2005. ${ }^{10}$ Most interestingly, this catalogue included a full color reproduction of the anonymous portrait of Antonio Ruffo in the Arciconfraternità degli Azzurri (which to that point had only been reproduced in black and white after a primitive photograph made by myself), where the text on the painted frame could be read: "D [on] Antonio Ruffo Principe della Scaletta Padre Governadore nel MDCLXXIII" (fig. 3). So, this was a portrait from 1673 of the man who had made the Aristotle and the Homer possible only a few years earlier.

Pavone also sent me a book by Rosanna De Gennaro, Per il collezionismo del Seicento in Sicilia: L'inventario di Antonio Ruffo principe della Scaletta, published in Pisa in 2003. In this book De Gennaro published an inventory she had found in the Archivio di Stato in Naples, dated to 1660, which is the first date in that manuscript. This inventory gives the most extensive description of the three paintings:

Del Reimbrant pittore olandese stimatissimo e raro, tre quadri con 3 meze figure grandi al naturale, di palmi 8 e 6: il meglio è d'un Aristotile o sia Alberto Magno che tiene la man dritta sopra una testa che sta sul boffettino, considerando la fisionomia, vestito di bianco e negro a guisa di monaco, et una catena al collo con la sua medaglia, et uno anelletto al dito, l'altra mano alla centora; l'altro d'un Alessandro Magno che sta a sedere col suo spatone e lancia a lato; et altro Omero anche a sedere su una sedia di legno che sta 
insegnando 2 discepoli; con loro cornice intagliate uniforme et adorata, gli quadri mi costorono scudi mille. ${ }^{11}$

Interesting points in this description are that Rembrandt is mentioned as "pittore olandese stimatissimo e raro," (a very much esteemed and special Dutch painter), that the Aristotle is considered the best painting (of the three), and that the figure in that work is dressed in the manner of a monk. Also we see that the figure in Alexander the Great is standing with a sword and lance at his side.

8 Pavone sent me three more articles that year, also written by De Gennaro, one of which is important for the history of the collection of Antonio Ruffo. In this article De Gennaro published the notarial list indicating that the one hundred or so most important paintings from Ruffo's collection were to be inherited by the firstborn child ("vincolati in primogenitura") and not spread among several children. ${ }^{12}$ The list enumerates 112 paintings, which were rescued by Don Giovanni Ruffo from the earthquake of February 5, 1783, and brought to Scaletta. If the two works on the list by Rosa, “[Due] quadri della Trasmigrazione di Pitagora, di Salvator Rosa, palmi 5 e 7, onze 180," are identical with the two paintings mentioned above as being in England by 1770, which also measure palmi 5 and 7, then the former identification should be revised, because they were apparently still in Sicily at that time.

A comparison of the list with earlier inventories shows that many paintings were lost. For example, of the pendants painted by Italian artists to accompany the paintings by Rembrandt, only the "Cosmografo" by Guercino is listed, and the paintings by Mattia Preti (Dionysius of Syracuse), by Salvator Rosa (The Philosopher Archita Tarantino), and by Giacinto Brandi (The Philosopher or Hieronymus) are missing.We find in "Nella camera grande" an "[A]lessandro Magno, del Reimbrant, sono tre onze 210," in "Nel camerino" a "Quadro di Alberto Magno, del Reimbrant, palmi 5 $1 / 2$, sono tre, onze 210," and in the "Retro camera" "Un quadro di Omero, del Reimbrant, sono tre, onze 210." ${ }^{13}$ Alexander the Great is thus in the large room, the New York Aristotle is in the small room, described as "Alberto Magno" (Albert the Great) and the Homer is in the back room. Thus, the three were not displayed close to each other anymore. Moreover, the size of the Aristotle is given in the list as $5 \frac{1}{2}$ palmi, which means, if we take the Sicilian palmo as $25.8 \mathrm{~cm}$, it measured $141.9 \mathrm{~cm}$, which is almost the same as the height currently given for the New York painting, 143.5 $\mathrm{cm}$. If the painting has been cut down, as has been suggested, this must have been done before $1783 .{ }^{14}$

10 Another consequence of this inventory of 1783 is that the "Alessandro Magno," or Alexander the Great, can definitely not be identical with the painting A Man in Armor, now in Glasgow (Kelvingrove Art Gallery and Museum), as has often been thought, because Ruffo's Alexander was still in Sicily in 1783, whereas the Glasgow painting was already in the collection of Joshua Reynolds in 1764. I argued against this identification in my book of $1999 .{ }^{15}$

11 My supposition that Ruffo's collection was disbursed around 1750, based on the lack of inventories, has thus proved to be incorrect given the existence of an inventory of later date that includes the Rembrandts. However, there is no known inventory of the collection of Don Giovanni when he died in 1802, so the collection could have been dispersed before that date. We still have a gap 
after 1783. Liedtke proposed that the next known sighting of two of the Rembrandts was at a sale in London, on February 17, 1810, where they appeared as no. 113 (Rembrandt, "A Portrait of a Sculptor with a Bust $£ 79$ 16s.") and no. 114 (Rembrandt, "The Companion, a Schoolmaster with his Pupil $£ 32$ 11s."). These must be the Aristotle and the Homer, but the Alexander the Great is missing, and it is not known what happened to it. The Aristotle and the Homer both show traces of burning and large pieces of the Homer are missing. Possibly the paintings suffered during the earthquake of 1783, and perhaps the Alexander was so damaged that it was considered no longer worth saving.

12 These remarks are a kind of refinement of some details in Liedtke's entry. It would have been very important to have his sharp comments on this note, but to my deep regret this is no longer possible.

\section{Acknowledgements}

With thanks to Stephanie Dickey for editorial comments. Some of the evidence discussed here was presented in: Jeroen Giltaij, "Nieuws omtrent Ruffo en Rembrandt," Kroniek van het Rembrandthuis (2005): 47-49.

Jeroen Giltaij studied art history in Amsterdam. In 2012 he retired from the Museum Boijmans van Beuningen in Rotterdam, where he was appointed Assistant Curator of Drawings in 1972, Chief Curator of Old Master Paintings and Sculpture in 1978, and Senior Curator in 1996. He is the author of numerous exhibition catalogues, journal articles, and other publications.

jgiltay@xs4all.nl

\section{List of Illustrations}

Fig. 1 Anonymous, Portrait of Antonio Ruffo, 1673, oil on canvas, approx. 90 x 65 cm, Messina, Arciconfraternità degli Azzurri (artwork in the public domain)

Fig. 2 Rembrandt, Homer Dictating His Verses, 1663, oil on canvas, 107 x $82 \mathrm{~cm}$, signed and dated . . andt f. 1663. The Hague, Mauritshuis, inv. 584 (artwork in the public domain)

Fig. 3 Rembrandt, Aristotle with a Bust of Homer, 1653, oil on canvas, 143.5 x $136.5 \mathrm{~cm}$, signed and dated Rembrandt.f./1653. New York, The Metropolitan Museum of Art, inv. 61.198 (artwork in the public domain)

${ }^{1}$ Walter Liedtke, Dutch Paintings in the Metropolitan Museum of Art, 2 vols. (New York: Metropolitan Museum of Art/New Haven: Yale University Press, 2007.

${ }^{2}$ Walter Liedtke, Dutch Paintings, no. 151. For an updated bibliography on Aristotle with a Bust of Homer, see the Metropolitan Museum of Art website: http://www.metmuseum.org/art/collection/ 
search/437394 (accessed May 15, 2016).

${ }^{3}$ Jeroen Giltaij and Guido Jansen, eds., Perspectives: Saenredam and the Architectural Painters of the 17th Century, exh. cat. (Rotterdam: Museum Boijmans van Beuningen, 1991), 31-42.

${ }^{4}$ The members of the jury were Sydney J. Freedberg, Michel Laclotte, Neil MacGregor, Jennifer Montagu, Konrad Oberhuber, Alfonso E. Pérez Sanchez, Pierre Rosenberg, Willibald Sauerländer, Seymour Slive, and Jean Sutherland-Boggs.

${ }^{5}$ Jeroen Giltaij, Ruffo en Rembrandt: Over een Siciliaanse verzamelaar in de zeventiende eeuw die drie schilderijen bij Rembrandt bestelde (Zutphen: Walburg Pers, 1999).

${ }^{6}$ These were published by the heirs but only seen in original by Corrado Ricci; see Vincenzo Ruffo, "Galleria Ruffo nel secolo XVII in Messina (con lettere di pittori ed altri documenti inediti)," Bollettino d'Arte 10 (1916): 21-64, 95-128, 165-92, 237-56, 284-320, 369-88; and Vincenzo Ruffo, "La Galleria Ruffo (appendice)," Bollettino d’Arte 13 (1919): 3-16; and Corrado Ricci, Rembrandt in Italia (Milan, 1918), 7-53.

7 "And further three paintings with three half-figures of natural size of palmi 8 and 6, one Aristotle or also Albert the Great, who keeps his right hand on a statue, and the other Alexander the Great, who is sitting, and the other Homer also sitting, who is teaching two pupils, all with their carved frames, from the hand of Rembrandt, Dutch painter."

${ }^{8}$ Luigi Salerno, I dipinti del Guercino (Rome, 1968), no. 256.

${ }^{9}$ Luigi Salerno, Salvator Rosa (Milan, 1963), 131, no. 68.

${ }^{10}$ Jeroen Giltaij, "Antonio Ruffo e Rembrandt," in Percorsi d'arte, tra vestigia dei Messapi il collezionismo dei Ruffo e l'evoluzione pittorica di Mino Delle Site, exh, cat. (Cavallino: Convento di S. Domenico, and Salerno: Pinacoteca Provinciale, 2005), 51-63.

11 "By Rembrandt, Dutch painter very highly esteemed and rare, three paintings with three half-figures of natural size, of palmi 8 and 6: the best one is of an Aristotle or also Albert the Great, who keeps his right hand on a statue which stands on a sideboard, contemplating the features, dressed in white and black in the manner of a monk, and a chain around the neck with the medal and a ring at it, the other hand at the belt and the other an Alexander the Great who is standing with his sword and a lance at his side; and the other Homer also sitting on a wooden chair who is teaching two pupils; with their carved and equal frames and guilded, the paintings had costed me a thousand scudi." Rosanna De Gennaro, Per il collezionismo del Seicento in Sicilia: L'inventario di Antonio Ruffo principe della Scaletta (Pisa: Scuola normale superiore, 2003), 129.

${ }^{12}$ Rosanna De Gennaro, "Un inventario ritrovato della collezione di don Antonio Ruffo: precisazione su Brueghel, Ribera e Savoldo," Prospettiva 87-88 (1997): 168-74; Rosanna De Gennaro, “Un fiammingo a Messina: Abraham Casembrot," Prospettiva 93-94 (1999): 189-99; and Rosanna De Gennaro, "Aggiunta alle notizie sulla collezione di Antonio Ruffo. $<$ Nota di quadri vincolati in primogenitura.> scampati al terremoto del 5 febbraio 1783," Napoli Nobilissima 2 (2001):211-15. Because it is important and could have escaped Rembrandt scholars, I have earlier cited this publication: Jeroen Giltaij, "Nieuws omtrent Ruffo en Rembrandt," Kroniek van het Rembrandthuis (2005): 47-49.

${ }^{13}$ De Gennaro, “Aggiunta alle notizie sulla collezione di Antonio Ruffo," 214.

${ }^{14}$ See my entry and that of Hubert von Sonnenburg in Rembrandt/Not Rembrandt, exh. cat., ed. Walter Liedtke, Carolyn Logan, Nadine M. Orenstein, and Stephanie S. Dickey (New York: The Metropolitan Museum of Art, 1995), 68, no. 11; and 59, fig. 75.

${ }^{15}$ See Giltaij, Ruffo en Rembrandt, 63. 


\section{Bibliography}

De Gennaro, Rosanna. "Aggiunta alle notizie sulla collezione di Antonio Ruffo. $<$ Nota di quadri vincolati in primogenitura.> scampati al terremoto del 5 febbraio 1783." Napoli Nobilissima 2 (2001): 211-15.

De Gennaro, Rosanna. Per il collezionismo del Seicento in Sicilia: L'inventario di Antonio Ruffo principe della Scaletta. Pisa: Scuola normale superiore, 2003.

De Gennaro, Rosanna. “Un fiammingo a Messina: Abraham Casembrot."Prospettiva 93-94 (1999): 189-99.

De Gennaro, Rosanna. "Un inventario ritrovato della collezione di don Antonio Ruffo: precisazione su Brueghel, Ribera e Savoldo." Prospettiva 87-88 (1997): 168-74.

Giltaij, Jeroen. “Antonio Ruffo e Rembrandt." In Percorsi d'arte, tra vestigia dei Messapi il collezionismo dei Ruffo e l'evoluzione pittorica di Mino Delle Site, exh, cat., 51-63. Cavallino: Convento di S. Domenico, and Salerno: Pinacoteca Provinciale, 2005.

Giltaij, Jeroen. "Nieuws omtrent Ruffo en Rembrandt." Kroniek van het Rembrandthuis (2005): 47-49.

Giltaij, Jeroen. Ruffo en Rembrandt: Over een Siciliaanse verzamelaar in de zeventiende eeuw die drie schilderijen bij Rembrandt bestelde. Zutphen: Walburg Pers, 1999.

Giltaij, Jeroen, and Guido Jansen eds. Perspectives: Saenredam and the Architectural Painters of the 17th Century. Exh. cat. Rotterdam: Museum Boijmans Van Beuningen, 1991.

Liedtke, Walter. Dutch Paintings in the Metropolitan Museum of Art. 2 vols. New York: The Metropolitan Museum of Art/New Haven: Yale University Press, 2007.

Ricci, Corrado. Rembrandt in Italia. Milan, 1918.

Ruffo, Vincenzo. "Galleria Ruffo nel secolo XVII in Messina (con lettere di pittori ed altri documenti inediti)." Bollettino d'Arte 10 (1916): 21-64, 95-128, 165-92, 237-56, 284-320, 369-88.

Ruffo, Vincenzo. “La Galleria Ruffo (appendice).” Bollettino d’Arte 13 (1919): 3-16.

Recommended Citation:

Jeroen Giltaij, "A Note on Rembrandt's Aristotle, Alexander, and Homer," JHNA 9:1 (Winter 2017), D0I: 10.5092/jhna.2017.9.1.14 